\title{
INFEKSI JAMUR PADA GERIATRI
}

\author{
Yosa Tamia Marisa ${ }^{1)}$, Roza Mulyana ${ }^{2)}$ \\ ${ }^{1}$ sub-bagian Geriatri dan Gerontologi, Bagian Penyakit dalam, RSUP Dr. M. Djamil Padang \\ email: yossamarisa@gmail.com
}

\section{Submitted : 20-01-2020,Reviewer:21-01-2020, Accepted: 23-01-2020}

\begin{abstract}
Elderly patients need special and thorough attention, because in elderly patients often occur more than one disease multipatologi. One of them is an infectious disease that is prone to occur in elderly patients due to decreased functional body reserve, decreased immunity, repeated hospital stays, diagnosis and therapy that is often late, decreased response to antibiotic therapy, and increased potential for side effects and interactions between drug. Fungi infections are an increasing problem in the elderly population including opportunistic fungi infections in elderly patients with immunocompromised conditions with multipatolgi disease and coincidence, post chemotherapy in malignancies, posttransplantation, or receive immunosuppressant therapy due to dermatological and rheumatological diseases.
\end{abstract}

Keywords: fungi infection, geriatric, immunosence

\begin{abstract}
Abstrak
Pasien usia lanjut atau geriatri membutuhkan perhatian khusus dan menyeluruh karena seringnya kejadidan multipatologi penyakit. Salah satunya yaitu penyakit infeksi yang rentan terjadi pada pasien usia lanjut karena penurunan cadangan fungsional tubuh, penurunan imunitas, rawatan rumah sakit berulang kali, diagnosis dan terapi yang sering terlambat, penurunan respon terhadap terapi antibiotik, dan meningkatnya potensi efek samping serta interaksi antar obat atau polifarmasi. Infeksi jamur merupakan masalah yang terus meningkat pada populasi lansia diantaranya infeksi jamur oportunistik dengan keadaan imunokompromais dan multipatolgi penyakit serta koinsidensi, post kemoterapi pada keganasan, pasca transplantasi, atau mendapat terapi imunosupresan karena penyakit dermatologis dan reumatologis .
\end{abstract}

Kata kunci: infeksi jamur, geriatric,immunosence 


\section{PENDAHULUAN}

Penduduk lanjut usia atau geriatri di seluruh dunia diproyeksikan tumbuh dengan sangat cepat, bahkan tercepat dibanding kelompok usia lainnya. Pada tahun 2012, Indonesia memiliki 25 juta lansia dan merupakan negara Asia ketiga yang memiliki populasi lansia terbanyak setelah Cina 200 juta dan India 100 juta. Tahun 2014, usia harapan hidup Indonesia yaitu 72 tahun, sedangkan di Jepang 84 tahun, Korea selatan 82 tahun dan Amerika 79 tahun. ${ }^{1}$

Pasien usia lanjut membutuhkan perhatian khusus dan menyeluruh, karena pada pasien usia lanjut sering terjadi lebih dari satu penyakit atau multipatologi. Salah satunya yaitu penyakit infeksi yang rentan terjadi pada pasien usia lanjut karena penurunan cadangan fungsional tubuh, penurunan imunitas, rawat inap di RS yang berulang kali, diagnosis dan terapi yang sering terlambat, penurunan respon terhadap terapi antibiotik, dan meningkatnya potensi efek samping serta interaksi antar-obat. ${ }^{2}$

Geriatrimengalami

immunosenscence yaitu menurunnya kekebalan tubuh pada seseorang terhadap paparan antigen dari luar karena usia. Sehingga respon imun tubuh terhadap pertahanan infeksi menurun. Akibatnya geriatri rentan terkena infeksi dan sering disertai dengan komplikasi yang berat. Bila sudah terinfeksi maka pengendalian penyakitnya akan lebih sulit, sehingga meningkatkan angka mortalitas pada usia lanjut. Infeksi pada usia lanjut bisa disebabkan oleh bakteri, virus, jamur dan mikroorganisme lainnya. ${ }^{1}$

Penuaan dikaitkan dengan penurunan beberapa fungsi kekebalan tubuh. ${ }^{10}$ Penuaan juga dikaitkan dengan semacam paradox yakninya keadaan peningkatan autoimunitas dan peradangan dengan keadaan defisiensi imun. Immunosenescence adalah konsep baru yang mencerminkan perubahan imunologis yang terkait dengan usia. ${ }^{11}$ Ada tiga teori yang menjelaskan fenomena immunosenescence yaitu: teori autoimmune, teori imunodefisiensi, teori disregulasi.

Teori penuaan autoimun pertama kali diperkenalkan oleh Walford tahun 1969. Menurut teori ini, sistem kekebalan tubuh cenderung kehilangan efisiensi dan mengalami disfungsi yang meluas, dibuktikan dengan autoimunitas reaksi kekebalan terhadap protein tubuh sendiri. ${ }^{12}$ Produksi autoantibodi telah dihipotesiskan akibat involusi timus dengan penurunan sel $\mathrm{T}$ naif dan akumulasi sel $\mathrm{T}$ klonal pada keadaan lanjut usia. ${ }^{13}$

Teori imunodefisiensi menyatakan bahwa dengan bertambahnya usia, tubuh tidak dapat mempertahankan diri dari patogen. ${ }^{14}$ Bukti klinis menunjukkan bahwa dengan bertambahnya usia, respons imun terhadap antigen berkurang dan kemampuan untuk merangsang respons imun primer terhadap antigen baru menurun secara signifikan. Gangguan kemampuan untuk meningkatkan respons imun terhadap antigen baru dapat mengakibatkan kerentanan terhadap penyakit menular. ${ }^{15}$ Respons imun terhadap antigen bergantung pada sel $\mathrm{T}$ naif. ${ }^{15}$ Imunodefisiensi dan involusi timus yang berkaitan dengan usia akan mengakibatkan openurunan sel $\mathrm{T}$ CD8 + naiff, situasi ini membuat tubuh praktis kekurangan sel $\mathrm{T}$ naï yangyang mengakibatkan tubuh lebih rentan terhadap berbagai infeksi dan penyakit menular ataupun penyakit tidak menular. ${ }^{15}$

Teori deregulasi menyatakan penuaan dikaitkan dengan berbagai perubahan dalam parameter kekebalan tubuh. Deregulasi dalam respons sistem kekebalan tubuh terutama terjadi pada usia tua. ${ }^{16}$ hal ini Ini didukung oleh gangguan 
terkait keseimbangan isoform imunitas. Disregulasi dari sistim imun ini berhubungan dengan risiko infeksi, termasuk jamur komensal di tubuh.

Infeksi jamur saat ini menjadi masalah yang terus meningkat pada populasi geraitri karena keadaan imunokompromais uang berhubungan dengan usia lanjut, post kemoterapi pada keganasan, pasca transplantasi, atau mendapat terapi imunosupresan karena penyakit dermatologis dan reumatologis. ${ }^{2}$

\section{ASPEK KLINIS INFEKSI JAMUR PADA USIA LANJUT}

\section{Mikosis Endemik}

\section{a) Histoplasmosis pulmonal kronik}

Diantara mikosis endemik, histoplasmosis bersifat unik pada beberapa manifesasi infeksi yang ditemukan pada usia lanjut. Histoplasmosis pulmonal kronik hampir selalu terjadi pada pasien yang mengalami emfisema. Infeksi ini terjadi secara progresif karena host tidak mampu mengeradikasi organisme dari paru yang mengalami emfisema berat. Manifestasi infeksi ini menyerupai reaktivasi tuberkulosis : demam, keringat malam, anoreksia, penurunan berat badan, batuk kronis dengan produksi sputum, hemoptisis, dan dispnea. Rontgen thoraks pasien menunjukkan kavitas dan infiltrat pada lobus atas baik unilateral maupun bilateral. 3

\section{b) Histoplasmosis progresif kronik diseminata \\ Bentuk kedua histoplasmosis} yang biasanya terdapat pada usia lanjut yaitu histoplasmosis progresif kronik diseminata. Pasien dengan penyakit ini tidak secara jelas mengalami imunosupresi tetapi mengalami defek selektif pada imunitas dimediasi sel terhadap H.capsulatum. Penyakit ini ditandai dengan paratisasi pada sistem retikuloendoplasma. Makrofag pada kelenjar getah bening, hati, limpa sumsum tulang dan paru mengandung banyak jamur. Pasien akan mengalami demam, keringat malam, anoreksia, penurunan berat badan, dan fatigue. Pada pasien kadang juga ditemukan adanya ulkus mukokutan. Pansitopenia dan peningkatan alkali fosfatase sering dijumpai. Keterlibatan kelenjar adrenal difus dapat menyebabkan penyakit Addison dengan manifestasi kelemahan, hipotensi ortostatik, hiperkalemia dan hiponatremia. Rontgen thoraks seringkali menunjukkan infiltrat difus. Bentuk histoplasmosis ini bersifat fatal jika tidak ditatalaksana segera. ${ }^{3}$

c) Blastomikosis

Blastomikosis pada pasien usia lanjut hampir sama pada pasien usia muda. Infeksi paru kronis dapat menyerupai tuberkulosis atau histoplasmosis kavitari kronis. Akan tetapi, infeksi paru yang disertai dengan distres pernafasan lebih sering terjadi pada usia lanjut. Lesi kutaneus sering menjadi satu-satunya manifestasi klinis yang jelas pada infeksi diseminata oleh Blastomyces dermatitidis, tetapi dapat juga kadang ditemukan keterlibatan genitourinaria dan osteoartikular. ${ }^{4}$

d) Koksidioidomikosis

Pasien usia lanjut lebih cenderung mengalami komplikasi akibat infeksi C.immitis, karena adanya penurunan sistem imun ataupun adanya penyakit penyerta 
seperti diabetes melitus yang menjadi faktor risiko koksidioidomikosis pulmonal berat. Manifestasi klinis koksidioidomikosis diseminata, termasuk lesi kutaneus, keterlibatan osteoartikular, dan meningitis tidak berbeda pada usia lanjut maupun dewasa muda. 5

\section{Infeksi Jamur Oportunis tik}

\section{a. Kandidias is}

Infeksi jamur oportunistik yang paling sering terjadi pada semua usia yaitu kandidiasis dengan manifestasi klinis berupa demam, menggigil, lesi kulit pustular, dan sepsis. Lesi retina harus dicari pada seluruh pasien candidemia akan tetapi kadang sulit ditemukan pada pasien usia lanjut yang mengalami katarak. Peningkatan usia berkaitan dengan mortalitas yang tinggi. Pada pasien usia lanjut dengan penyakit dasar multipel serta panjangnya durasi rawatan di ruang intensif, Candidemia merupakan penanda outcome yang buruk. 6

\section{b. Kriptokokkosis}

Kriptokokkosis merupakan infeksi oportunistik yang cukup sering pada usia lanjut yang tidak menderita AIDS yang diterapi dengan kortikosteroid, menjalani transplantasi organ, diabetes melitus, gagal ginjal, gangguan hati, atau PPOK. Sekitar 20\% pasien denan kriptokokosis tidak memiliki faktor risiko dan kebanyakan merupakan usia lanjut. Pasien usia lanjut dengan meningitis kriptokokosis kadang hanya mengalami klinis demensia, tanpa adanya demam, sakit kepala atau defisit neurologis fokal lainnya. Outcome yang buruk pada infeksi kriptokokkal ditemukan pada usia lanjut (>60 tahun). ${ }^{7}$

c. Infeksi oportunistik jamur berfilamen

Manifestasi klinis infeksi invasif jamur berfilamen (aspergillus dan zygomycetes) hampir sama dengan usia muda. Kondisi imunokompromais pada pasien menjadi determinan penting dari manifestasi klinis dan dapat menyebabkan infeksi yang mengancam nyawa. Akan tetapi terdapat beberapa manifestasi aspergilosis yang sering ditemukan pada usia tua yaitu aspergilosis sinoorbital berupa nyeri orbita, proptosis, ophtalmoplegia, dan kehilangan penglihatan. Aspergilosis pulmonal nekrosis kronis merupakan infeksi subakut yang banyak terjadi pada usia paruh baya dan usia lanjut. Gejala menyerupai pneumonia yang tidak berespon dengan antibiotik dan mengalami progresivitas pada kelainan paru dan pleura. ${ }^{8}$

\section{PENATALAKSANAAN JAMUR PADA USIA LANJUT}

Indikasi penggunaan anti jamur dalam tatalaksana infeksi jamur spesifik sama pada usia lanjut maupun pada dewasa. Panduan yang biasanya digunakan yaitu dari Infectious Disease society of America. ${ }^{2}$

\section{a. Golongan Azol}

Azol merupakan agen pilihan untuk terapi pasien dengan mikosis endemik dan infeksi jamur lokal, serta berperan penting dalam tatalaksana kandidiasis sistemik dan infeksi kriptokokus. Secara umum, agen azol bersifat lebih aman daripada amfotericin B. Bentuk oral dari flukonazol memiliki bioavailabilitas hampir $100 \%$ dan tidak membutuhkan asam lambung atau 
makanan untuk penyerapannya. Sementara itu, asam lambung dibutuhkan untuk penyerapan ketokonazol tablet dan itrakonazol kapsul. Oleh karena itu, pasien usia lanjut yang lebih cenderung mengalami aklorhidria sulit mengabsorbsi obat ini secara adekuat. Selain itu pemberian $\mathrm{H} 2$ bloker, antasida, dan PPI perlu dihindari pada pasien yang mendapat ketokonazol atau itrakonazol. Oleh karena itu, untuk mengoptimalkan penyerapannya bentuk suspensi oral dari itrakonazole diberikan pada saat sebelum makan. ${ }^{1}$

Interaksi dengan obat lain dapat terjadi, terutama itrakonazol dan ketokonazol, karena efeknya terhadap sistem P450 sitokrom. Kadar warfarin, fenitoin, dan obat hipoglikemik oral pada serum dapat meningkat karena obat azol,dan kadar digoksin dapat meningkat karena itrakonazole pada beberapa pasien. Itrakonazole juga sebaiknya tidak diberikan pada pasien yang mendapat obat antikolesterol seperti simvastatin dan lovastatin karena risiko rhabdomiolisis. Azol juga tidak boleh diberikan pada pasien yang mendapat obat yang dapat menyebabkan pemanjangan inerval QT, seperti cisapride, astemizole, tefenadine karena risiko aritmia ventrikel. ${ }^{1}$

Efek samping juga dapat timbul pada penggunaan azol, seperti gangguan fungsi hati, ruam dan mual. Pada usia tua cukup sering dijumpai komplikasi yang jarang akibat itrakonazol seperti hipertensi, edema dan hipokalemia. Alopesia dapat dijumpai pada penggunaan flukonazol jangka panjang. Ketoconazol dosis tinggi (400-800 $\mathrm{mg}$ ) dapat menyebabkan penekanan steroid androgenik dan glukokortikoid yang menyebabkan ginekomastia, oligospermia, dan insufisiensi adrenal. ${ }^{2}$

\section{b. Amfoterisin B}

Amfoterisin B tetap menjadi agen pilihan dalam tatalaksana infeksi jamur berfilamen dan infeksi kandida tertentu serta untuk terapi awal meningitis kriptokokal dan mikosis endemik yang mengancam nyawa. Akan tetapi, agen ini secara intrinsik bersifat nefrotoksik dan berkaitan dengan sejumlah efek samping akibat pemberian intravena seperti demam, kaku, mual, sakit kepala dan nyeri sendi. ${ }^{2}$

\section{c. Micafungin}

Micafungin merupakan obat anti jamur golongan echinocandin yang digunakan untuk mengatasi infeksi jamur dengan cara menghambat produksi beta 1,3 glukan yang merupakan komponen penting dari dinding sel jamur. Micafungin diberikan secara intravena dan diindikasikan sebagai pengobatan kandidemia, kandidiasis diseminata akut, peritonitis kandida, abses dan kandidiasis esofagus. Selain itu, micafungin juga dapat digunakan sebagai profilaksis pada pasien yang imunokompromais seperti pasca transplantasi sel hematopoietik. ${ }^{9}$

\section{Daftar Pustaka}

1. Setiati S, Harimurti $K$, Govinda A. Proses menua dan implikasi kliniknya. In Buku ajar ilmu penyakit dalam jilid III Edisi 6. Jakarta: Interna Publisher; 2014. p. 3669-3679.

2. Kauffman C. Fungi infection in older adults. Clin Infect Dis. 2001; 33: p. 55055 .

3. Wheat J, Sarosi G, McKinsey D. Practice guidelines for the managements of patients with histoplasmosis. Clin Infect Dis. 2000; 30: p. 688-95.

4. Chapman S, Bradsher R, Campbell G. Practice guidelines for the management of patients with blastomycosis. Clin 
Infect Dis. 2000; 30: p. 679-83.

5. Galgiani J, Ampel N, Catanzaro A. Practice guidelines for the treatment of coccidioidomycosis. Clin Infect Dis. 2000; 30: p. 658-61.

6. Rex J, Walsh T, Sobel J. Practice guidelines for the treatment of candidiasis. Clin Infect Dis. 2000; 30: p. 662-78.

7. Saag M, Graybill J, Larsen R. Practice guidelines for the management of cryptococcal disease. Clin Infect Dis. 2000; 30: p. 658-61.

8. Stevens D, Kan V, Judson M. Practice guidelines for diseases caused by Aspergillus. Clin Infect Dis. 2000; 30: p. 696-709.

9. Carver P. Micafungin. Annals of Pharmacotherapy. 2004; 38(10): p. 170721.

10. Burns ea and Goodwin JS. 1997. Immunodeficiency of Aging. Drugs \& Aging 11(5): 374-397.

11. Boraschi D and Italiani P. 2014. Immunosenescence and vaccine failure in the elderly: strategies for improving response. Immunol Lett 162(1): 346-353

12. Diggs J. 2008. Autoimmune Theory of Aging. In: Loue SJD and Sajatovic M (Eds), Encyclopedia of Aging and Public Health, Boston, MA: Springer US, p. 143-144.

13. Prelog M. 2006. Aging of the immune system: a risk factor for autoimmunity? Autoimmun Rev 5(2): 136-139.

14. Van Deursen JM. 2014. The role of senescent cells in ageing. Nature
509(7501): 439-446.

15. Fagnoni FF, Vescovini R, Passeri G, Bologna G, Pedrazzoni M, Lavagetto G, Casti A, Franceschi C, Passeri M and Sansoni P. 2000. Shortage of circulating naive $\mathrm{CD} 8(+) \mathrm{T}$ cells provides new insights on immunodeficiency in aging. Blood 95(9): 2860-2868.

16. Mcelhaney JE and Effros RB. 2009. Immunosenescence: what does it mean to health outcomes in older adults? Curr Opin Immunol 21(4): 418-424. 